\title{
Performance management system in Maharatna Companies (a leading public sector undertaking) of India - a case study of B.H.E.L., Bhopal (M.P.)
}

\author{
Rajesh K. Yadav*, Nishant Dabhade ${ }^{\star *}$ \\ Department of Management, RKDF College of Engineering, Bhopal - 462047, \\ Madhya Pradesh, India \\ *,**E-mail address: drrajeshkyadav@yahoo.com , nishant.dabhade.mgmt@gmail.com
}

\begin{abstract}
Extensive changes in the global economy have made it imperative for the governments all over the world to improve the quality of their governance structures. The Government of India has also introduced the New Public Management concepts in public administration with emphasis on 'results' or 'performance' to improve the efficiency and effectiveness of public services. This research aims to figure out the key variables that are having strong influence on Performance management system with special reference to BHEL, Bhopal (M.P.). Chi square test is applied in this paper to check the authenticity of data given by the respondents. We are also going to study the PM process, awareness level and satisfaction level of employees of BHEL and how the PM system affects the performance and career development of employees.
\end{abstract}

Keywords: Performance management; Public sector; Administration; Results etc.

\section{INTRODUCTION}

Performance management is a broad concept that involves understanding and acting on the performance issues at each level of organization, from individuals, teams and departments to the organization itself. These issues include leadership, decision making, motivation, encouraging innovation and risk taking among others. Performance management is a continuous process of identifying, measuring and developing the performance of individuals and teams and aligning performance with the strategic goals of the organization. It is the systematic description of an employee's strengths and weaknesses. Performance management may be undertaken at various levels of government and its purpose may differ depending on the level at which is it implemented. For example, it can be used to improve the performance of individual units (such as particular schools, hospitals, police forces). This may or may not be linked to 'best practice' exercises, in which the best performing units are used as an example for others to follow. It can be used as part of an attempt to improve the performance of the overall organization. A definition of performance management given by the Second Administrative Reforms Commission is as follows: 
"Performance management is the systematic process by which the organization involves its employees, as individuals and members of a group, in improving organizational effectiveness in the accomplishment of organizational mission and goals" $[6,13]$.

\section{PERFORMANCE MANAGEMENT SYSTEM}

An effective performance management system includes the following components:

\section{1. Performance Planning}

Performance planning is the first crucial component of any performance management process which forms the basis of performance appraisals. Performance planning is jointly done by the appraisee and also the appraiser in the beginning of a performance session. During this period, the employees decide upon the targets and the key performance areas which can be performed over a year within the performance budget. That is finalized after a mutual agreement between the reporting officer and the employee.

\section{2. Performance Appraisal and Reviewing}

The appraisals are normally performed twice in a year in an organization in the form of mid reviews and annual reviews which is held in the end of the financial year. In this process, the appraisee first offers the self-filled up ratings in the self-appraisal form and also describes his/her achievements over a period of time in quantifiable terms. After the self-appraisal, the final ratings are provided by the appraiser for the quantifiable and measurable achievements of the employee being appraised. The entire process of review seeks an active participation of both the employee and the appraiser for analyzing the causes of loopholes in the performance and how it can be overcome. This has been discussed in the performance feedback section.

\section{3. Feedback on the Performance followed by personal counseling and performance facilitation}

Feedback and counseling is given a lot of importance in the performance management process. This is the stage in which the employee acquires awareness from the appraiser about the areas of improvements and also information on whether the employee is contributing the expected levels of performance or not. The employee receives an open and a very transparent feedback and along with this the training and development needs of the employee is also identified. The appraiser adopts all the possible steps to ensure that the employee meets the expected outcomes for an organization through effective personal counseling and guidance, mentoring and representing the employee in training programs which develop the competencies and improve the overall productivity.

\section{4. Rewarding good performance}

This is a very vital component as it will determine the work motivation of an employee. During this stage, an employee is publicly recognized for good performance and is rewarded. This stage is very sensitive for an employee as this may have a direct influence on the selfesteem and achievement orientation. Any contributions duly recognized by an organization helps an employee in coping up with the failures successfully and satisfies the need for affection. 


\section{5. Performance Improvement Plans}

In this stage, fresh set of goals are established for an employee and new deadline is provided for accomplishing those objectives. The employee is clearly communicated about the areas in which the employee is expected to improve and a stipulated deadline is also assigned within which the employee must show this improvement. This plan is jointly developed by the appraisee and the appraiser and is mutually approved.

\section{6. Potential Appraisal}

Potential appraisal forms a basis for both lateral and vertical movement of employees. By implementing competency mapping and various assessment techniques, potential appraisal is performed. Potential appraisal provides crucial inputs for succession planning and job rotation $[6,13,14]$.

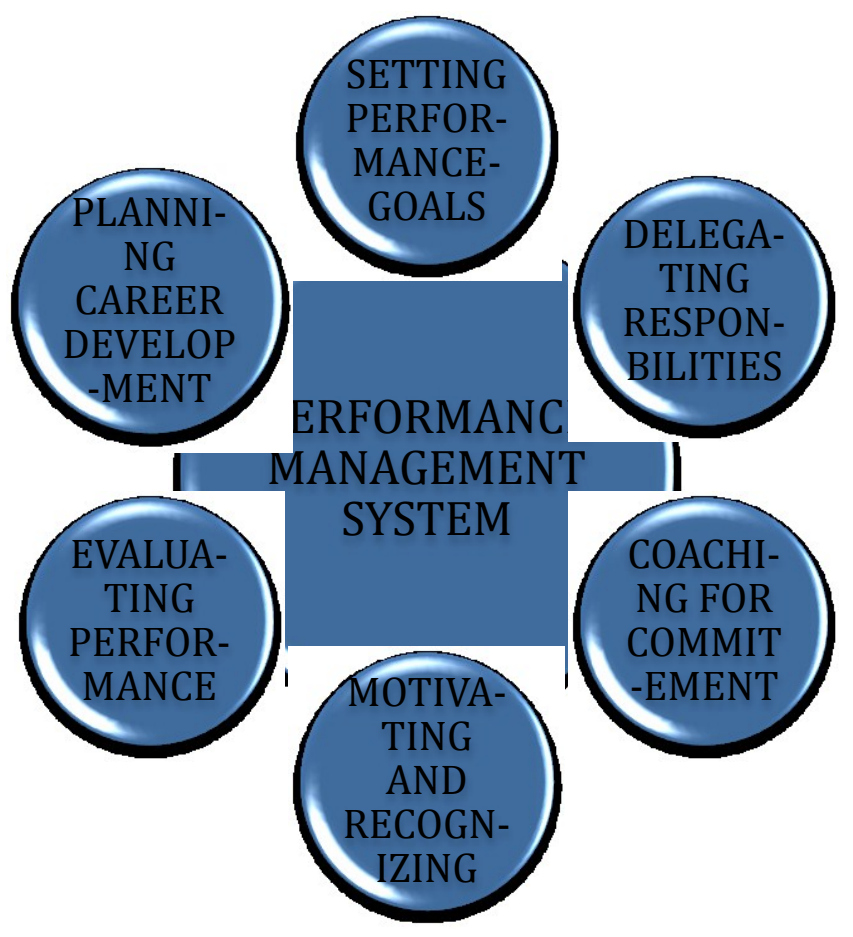

Fig. 1. Performance management system.

\section{OVERVIEW OF B.H.E.L., BHOPAL (M. P.)}

BHEL, Bhopal is an integrated power plant equipment manufacturer and one of the largest engineering and manufacturing companies in India in terms of turnover. We were established in 1964, ushering in the indigenous Heavy Electrical Equipment industry in India. BHEL is engaged in the design, engineering, manufacture, construction, testing, commissioning and servicing of a wide range of products and services for the core sectors of 
the economy, viz. Power, Transmission, Industry, Transportation (Railway), Renewable Energy, Oil \& Gas and Defense.

Most of its manufacturing units and other entities have been accredited to Quality Management Systems (ISO 9001:2008), Environmental Management Systems (ISO 14001:2004) and Occupational Health \& Safety Management Systems (OHSAS 18001:2007). BHEL have a share of $59 \%$ in India's total installed generating capacity contributing $69 \%$ (approx.) to the total power generated from utility sets (excluding non-conventional capacity) as of March 31, 2012.

Its greatest strength is highly skilled and committed workforce of 49,390 employees. Every employee is given an equal opportunity to develop himself/herself and grow in his/her career. Continuous training and retraining, career planning, a positive work culture and participative style of management - all these have engendered development of a committed and motivated workforce setting new benchmarks in terms of productivity, quality and responsiveness [1].

\section{KEY ISSUES AND CHALLANGES FOR PUBLIC SECTOR IN PERFORMANCE MANAGEMENT}

\section{1. Issues at Individual level}

Absence of quantification of targets and evaluation against achievement of targets.

$>$ Unclear performance standards.

$>$ Neglect of job fit in appointments, and frequent transfers.

$>$ Lack of mechanism to motivate for good performance.

$>$ Absence of appropriate punishment/reward mechanisms.

$>$ Absence of clear linkages between individual, organizational and program performance.

\section{2. Issues at Ministry/department level}

$>$ Funds granted to ministries are never linked with progress of work or the targets set out in the performance budget.

$>$ Lack of clarity regarding purpose and objectives of Action Plans.

$>$ Inability to measure performance in the absence of appropriate indicators.

\section{3. Issues at Public enterprise level}

$>$ Most PSUs rated excellent or good despite of declining performance.

$>$ Tendency of PSUs to show profits in the short-run by sacrificing long term interests.

$>$ Lack of scope for true negotiation.

$>$ No mechanisms to enable the movement of accountability to lower levels.

\section{4. Issues at program/ project level}

$>$ Focus on inputs and process compliance, neglects the outcomes and impacts.

$>$ Lack of measurable indicators.

$>$ Dichotomy between plans and budgets. $[6,9,12]$ 


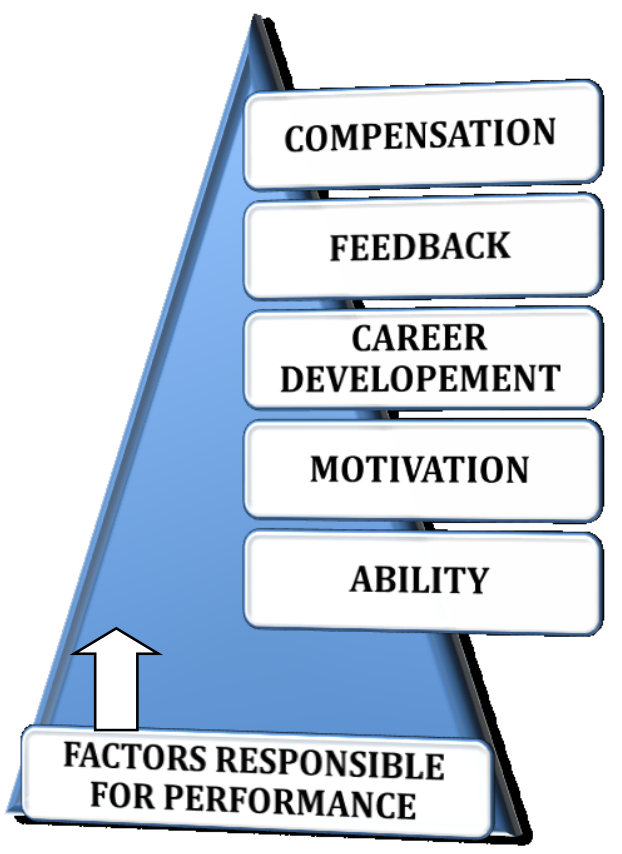

Fig. 2. Key factors affecting performance.

\section{GENERAL ERRORS IN PERFORMANCE MANAGEMENT SYSTEM}

While evaluating performance of the candidate under the PMS few types of error can take place that are as follows:

\section{1. Strictness Error}

It occur when the appraiser artificially assigns all or certain group of employees' low performance ratings and consequently all or certain scores cluster at the bottom of the rating scales.

\section{2. Central Tendency}

It is the tendency of the appraiser to avoid using the extremes of rating scales and to cluster the ratings around the midpoint.

\section{3. Spillover Effect}

It is the tendency of the appraiser to carry in mind the past performance of appraise in view while making evaluation on the present Performance.

\section{4. Recency Effect}

Sometimes the raters assign ratings on the basis of recent behavior they have seen in their appraisal forgetting about past behavior over a period. This is called recency effect [13$15]$. 


\section{RATIONAL OF THE STUDY}

The role of HR in the present scenario has undergone a sea change and its focus is on evolving such functional strategies which enable successful implementation of the major corporate strategies. In a way, HR and corporate strategies function in alignment. Today, HR works towards facilitating and improving the performance of the employees by building a conducive work environment and providing maximum opportunities to the employees for participating in organizational planning and decision making process. Today, all the major activities of HR are driven towards development of high performance leaders and fostering employee motivation. So, it can be interpreted that the role of HR has evolved from merely an appraiser to a facilitator and an enabler.

Performance management is the current buzzword and is the need in the current times of cut throat competition and the organizational battle for leadership. Performance management is a much broader and a complicated function of HR, as it encompasses activities such as joint goal setting, continuous progress review and frequent communication, feedback and coaching for improved performance, implementation of employee development programs and rewarding achievements. The process of performance management starts with the joining of a new incumbent in a system and ends when an employee quits the organization. Performance management can be regarded as a systematic process by which the overall performance of an organization can be improved by improving the performance of individuals within a team framework. It is a means for promoting superior performance by communicating expectations, defining roles within a required competence framework and establishing achievable benchmarks.

Hence, the main purpose of this research study is to investigate the key variables that are having strong influence on Performance management system with special reference to BHEL, Bhopal. We are also going to study the PM process, awareness level and satisfaction level of employees of BHEL and how the PM system affects the performance and career development of employees.

\section{REVIEW OF LITERATURE}

Sharmistha Bhattacharjee and Santoshi Sengupta (2011) studied that employees are the most valuable and dynamic assets of an organization. For achieving the strategic objective of sustained \& speedy growth, managing human resource has been featured as a vital requirement in all organizations. It is a challenge to monitor the entire cycle of defining the competence requirement of the business, accessing existing competence in the organization and bridging the gap between the two. HR practices are crucial for any organization. Every phase from recruitment to exit interview is under the HR department. It is a challenge to monitor the entire cycle of defining the competence requirement of the business, accessing existing competence in the organization and bridging the gap between the two. In a manufacturing industry, with every technical advancement business opportunities can show up. These opportunities can be converted into business success only with performance alignment and competence management [14].

The research paper of Mohammad Tanvi Newaz (2012) provides an analysis and evaluation of the role of performance management system in shaping psychological contract at Sainsbury's UK by a case study approach. Sainsbury's has adopted the performance 
management system to utilize the potential of their employees but result of data analysis indicates that line managers have failed to achieve the objective of the performance management system. This research analysis reveals how the line managers of Sainsbury's focus on short term goal i.e. financial success instead of long term goal i.e. employee development. However, the performance management system of Sainsbury's comprises all the necessary components to play a significant role in developing employees as well as facilitating the formation of a positive psychological contract. But partial and inattentive implementation of the system makes the situation unfavorable for the psychological contract to develop at Sainsbury's UK [11].

The article of Javed Iqbal, Samina Naz, Mahnaz Aslam, Saba Arshad (2012), offers a survey of selected literature on performance management. Purpose is to indentify key themes that govern the topic in the contemporary turbulent economic and business environment where employees are more uncertain that anything else because every day they face downsizing, volunteer retirement and 'golden hand shakes' to get rid of them. Under these circumstances it is worthwhile to look into the ways by which they can be motivated to work under hard conditions. It is found that performance management processes, evaluation, its impact and factors are key themes. Researchers apply popular research approaches for data collection analysis and communication [8].

The paper of Akua Asantewaa Aforo and Kodjo Asafo-Adjei Antwi (2012) shows that academic libraries have a performance appraisal system comprising setting of goals, feedback, participation and incentives for performance. This study aimed at evaluating the performance appraisal system in the KNUST and GIMPA libraries in Ghana and give recommendations on improving the system. Questionnaires were randomly administered to 46 staff members of these libraries [3].

The aim of this study of Akinyele S. T. (2010) was to evaluate the effectiveness of performance appraisal system at private universities in Nigeria. The focus of the study was on the administrative staff of Crawford University. The study evaluated the purpose of performance appraisal in private universities and identifies relevant factors for achieving an effective performance appraisal. A cross- sectional survey was selected for this study because it was easy to undertake compared to longitudinal survey and the results from the same can be inferred to the larger population. The study population was for all the administrative staff of Crawford University. The whole populations of staff were selected as respondents. A structured questionnaire was used to collect the data for analysis. The effectiveness of performance appraisal systems in private universities are only based on training the members of staff involved in the rating/ appraising process and are multi- rating systems. Conclusively because the performance appraisal systems used in private universities are not effective and that they exist just as a matter of formalities, the private universities cannot measure members of staff performance, hence making it difficult to achieve the intended human resource management objective [2].

The paper of Al Bento and Regina Bento (2006) proposes and tests a model to explain three critical outcomes of Performance Management Systems: information quality, effectiveness, and usefulness of the PMS to managerial decision-making. Drawing from Organizational Information Processing Theory (OIPT), we examined how those three outcomes may be influenced by factors that affect OIP requirements (industry, size, and geographic scope of operations) and by organizational and technological factors that affect OIP capabilities. Organizational factors included management's decision-making style and organizational structure. Technological factors included the types of technology used in the 
PMS (ERP; specialized tools such as EIS and DSS; and generic tools such as Excel, Access and Lotus Notes), and the degree of use of e-commerce and Internet technologies. [4]

The study of George Ndemo Ochoti, Elijah Maronga, Stephen Muathe, Robert Nyamao Nyabwanga, Peter Kibet Ronoh (2012) investigated the multifaceted factors influencing employee Performance Appraisal System in the Ministry of State for Provincial Administration, Nyamira District, Kenya. A target population of 76 employees was surveyed. A structured questionnaire was self-administered to the employees to collect data. Multiple regression analysis technique was used to explain the nature of the relationship between PAS and the factors that influence it. Results of the study showed that all the five factors: Implementation process (X1), interpersonal relationships (X2), rater accuracy (X3), informational factors (X4), and employee attitudes (X5) had a significant positive relationship with the performance appraisal system (Y). It shows that if these factors are taken into consideration by the ratees, the raters and the government policy makers, the PAS can be a good performance management tool [7].

This paper of Jawaria Andleeb Qureshi, Asad Shahjehan, Zia-ur-Rehman and Bilal Afsar (2010) notifies that many organizations install Performance Management Systems (PMS) formally and informally in their organizations, with the motivation to achieve better organizational results. In practice, organizations have difficulty in implementing a performance management system because its different dimensions are not taken into considerations enough. This article describes the findings of a comparative analyses conducted between a standard performance management model and performance management systems as applied by Local Development Organization (LDO). Data was collected from 50 employees of the organization with a Cronbach Alpha (0.935). Results identified barriers to implementation of effective PMS, also recommendations and viable solutions are presented [9].

Research of Leena Toppo, Twinkle Prusty (2012) informs that performance appraisal and performance management were one of the emerging issues since last decade. Many organizations have shifted from employee's performance appraisal system to employee's performance management system. This paper has focused to study the evolution of employee's performance appraisal system, critics the system suffered and how the performance management system came to the practice. The main purpose of this paper is to differentiate these two systems, employee's performance appraisal and management system. This paper uses a review of the literature to evaluate the development of appraisal system and argues the critic areas of appraisal system. Performance management eliminates the shortcomings of performance appraisal system to the some extent [12].

\section{RESEARCH METHEDOLOGY}

The study is a descriptive study. Questionnaire is designed to collect the data from various employees and staff members of BHEL, Bhopal (M. P.) [10].

\section{1. Objectives of the study}

- To study the process of performance management system followed by BHEL.

- To analyze the awareness and satisfaction level of employees towards PMS in BHEL.

- To study the impact of PMS on performance of the employee.

- To study the effects of PMS on career development of employees. 


\section{2. Hypothesis}

- Process of PMS followed by BHEL is effective.

- The employees of BHEL are satisfied with the PMS followed by the organization.

- There is a positive impact of PMS on the performance of the employees in BHEL.

- Effective PMS in BHEL plays vital role for career development of employees.

\section{3. Sampling plan}

- Sample Unit: Target groups (BHEL, Bhopal officials, employees and staff members)

- Sample Size: 250 (50 BHEL officials and 200 BHEL employees and staff members)

\section{4. Research approach}

Survey (Primary data is collected through self-structured questionnaire).

\section{QUESTIONNAIRE}

\section{1. Questionnaire for BHEL officials}

\section{1. 1. Performance Management System is clearly defined within the organization?}

\begin{tabular}{|c|c|c|c|}
\hline S. No. & OPINION & No. & PERCENT (\%) \\
\hline 1 & Agree & 20 & 40 \\
\hline 2 & To some extent & 17 & 34 \\
\hline 3 & Disagree & 05 & 10 \\
\hline 4 & Can't say & 08 & 16 \\
\hline Total & & 50 & 100 \\
\hline
\end{tabular}

When asked to the BHEL officials that PMS is clearly defined within the organization, majority of $40 \%$ people were agree and $34 \%$ of them were agree up to some extent while only $10 \%$ and $16 \%$ were disagree and can't say about it. The chi square value clearly indicates that opinion of the respondents was significantly different about this fact.

\section{1. 2. Performance Management System is a regular process in BHEL that comes after a defined time period?}

When it is asked to the BHEL officials that Performance Management System is a regular process in BHEL, then majority of $28 \%$ and $50 \%$ users were strongly agree and agree respectively while only $12 \%$ and $10 \%$ were disagree and strongly disagree respectively. The chi square value radically shows that opinion of the respondents was significantly different on asking PMS as a regular process. 


\begin{tabular}{|c|c|c|c|}
\hline S. No. & OPINION & No. & PERCENT (\%) \\
\hline 1 & Strongly agree & 14 & 28 \\
\hline 2 & Agree & 25 & 50 \\
\hline 3 & Disagree & 06 & 12 \\
\hline 4 & Strongly disagree & 05 & 10 \\
\hline Total & & 50 & 100 \\
\hline
\end{tabular}

9. 1. 3. The process of Performance management is transparent within the organization?

\begin{tabular}{|c|c|c|c|}
\hline S. No. & OPINION & No. & PERCENT (\%) \\
\hline 1 & Strongly agree & 11 & 22 \\
\hline 2 & Agree & 18 & 36 \\
\hline 3 & Disagree & 15 & 30 \\
\hline 4 & Strongly disagree & 06 & 12 \\
\hline Total & & 50 & 100 \\
\hline \multicolumn{4}{|c|}{$\chi^{2}=6.48, \mathrm{df}=3, \chi^{2}(.05)=7.81$} \\
\hline
\end{tabular}

When it is asked to the officials of BHEL that Performance management process is transparent within the organization, $22 \%$ and $36 \%$ were strongly agree and agree respectively and said that process is transparent And 30\% and $12 \%$ were disagree and strongly disagree correspondingly. The chi square value completely shows that the opinion of respondents was significantly identical when it comes to transparency of PMS.

\section{1. 4. Performance management process of BHEL furnishes a chance of advancement} and recognition to the employee?

\begin{tabular}{|c|c|c|c|}
\hline S. No. & OPINION & No. & PERCENT (\%) \\
\hline 1 & Strongly agree & 12 & 24 \\
\hline 2 & Agree & 24 & 48 \\
\hline 3 & Disagree & 08 & 16 \\
\hline 4 & Strongly disagree & 06 & 12 \\
\hline Total & & 50 & 100 \\
\hline \multicolumn{4}{|c|}{$\chi 2=15.6, \mathrm{df}=3, \chi 2(.05)=7.81$} \\
\hline
\end{tabular}


On asking to the officials of BHEL that PMS furnishes a chance of advancement and recognition to the employee, then group of $24 \%$ and $48 \%$ were strongly agree and agree respectively and only $16 \%$ and $12 \%$ were disagree and strongly disagree in that order. The chi square value entirely shows that the opinion of respondent was significantly different and majority of employees is in favor that PMS furnishes a chance of advancement and recognition.

\section{1. 5. All the factors facilitating and hindering performance are taken into consideration while appraising the performance?}

\begin{tabular}{|c|c|c|c|}
\hline S. No. & OPINION & No. & PERCENT (\%) \\
\hline 1 & Strongly agree & 15 & 30 \\
\hline 2 & Agree & 22 & 44 \\
\hline 3 & Disagree & 13 & 26 \\
\hline 4 & Strongly disagree & 00 & 00 \\
\hline Total & \multicolumn{2}{|c|}{$\chi^{2}=20.24, \mathrm{df}=3, \chi^{2}(.05)=7.81$} \\
\hline
\end{tabular}

When it is asked to the officials of BHEL factors facilitating and hindering performance are taken into consideration at the time of appraisal, then mass of $30 \%$ and $44 \%$ were strongly agree and agree respectively and only $26 \%$ were disagree on this fact. The chi square value radically shows that the opinion of respondents was significantly different.

\section{1. 6. Job Description of employees is clearly defined, on which your performance is rated?}

\begin{tabular}{|c|c|c|c|}
\hline S. No. & OPINION & No. & PERCENT (\%) \\
\hline 1 & Strongly agree & 15 & 30 \\
\hline 2 & Agree & 26 & 52 \\
\hline 3 & Disagree & 05 & 10 \\
\hline 4 & Strongly disagree & 04 & 08 \\
\hline Total & \multicolumn{2}{|c|}{$\chi^{2}=25.36, \mathrm{df}=3, \chi 2(.05)=7.81$} \\
\hline
\end{tabular}

On asking to the officials of BHEL that Job Description of employees is clearly defined within the organization then only $30 \%$ were strongly agree and as a group of $52 \%$ were agree and said that and $10 \%$ respondents were disagree and only $8 \%$ were strongly disagree about it. different.

The chi square value clearly indicates that the opinion of respondents was significantly 


\section{1. 7. Performance of employees improves due to current Performance Management System?}

\begin{tabular}{|c|c|c|c|}
\hline S. No. & OPINION & No. & PERCENT (\%) \\
\hline 1 & Strongly agree & 14 & 28 \\
\hline 2 & Agree & 27 & 54 \\
\hline 3 & Disagree & 06 & 12 \\
\hline 4 & Strongly disagree & 03 & 06 \\
\hline Total & & 50 & 100 \\
\hline
\end{tabular}

On asking to the official members that current Performance Management System improves Performance of employees then $28 \%$ were strongly agree and as a group of $54 \%$ were agree and said that PMS improves the performance of employees and only $12 \%$ respondents were disagree and $6 \%$ were strongly disagree about it. The chi square value clearly indicates that the opinion of respondents was significantly different on current PMS of BHEL.

\section{1. 8. Performance Management System helps employee to set and achieve meaningful goals?}

\begin{tabular}{|c|c|c|c|}
\hline S. No. & OPINION & No. & PERCENT (\%) \\
\hline 1 & Strongly agree & 16 & 32 \\
\hline 2 & Agree & 29 & 58 \\
\hline 3 & Disagree & 03 & 06 \\
\hline 4 & Strongly disagree & 02 & 04 \\
\hline Total & \multicolumn{2}{|c|}{50} & 100 \\
\hline
\end{tabular}

When it is asked to the officials of BHEL that PMS helps employee to achieve meaningful goals, then mass of $32 \%$ and $58 \%$ were strongly agree and agree respectively and only $6 \%$ and $4 \%$ were disagree and strongly disagree correspondingly on this fact. The chi square value radically shows that the opinion of respondents was significantly different when talking about achieving meaningful foals due to PMS.

\section{1. 9. The PMS implemented in your organization create a participative environment?}

On asking to the officials of BHEL that PMS create a participative environment then only $18 \%$ were strongly agree and as a group of $50 \%$ were agree and said that it creates participative environment in our organization and $18 \%$ respondents were disagree and only 14 
$\%$ were strongly disagree about it. The chi square value clearly indicates that the opinion of respondents was significantly different.

\begin{tabular}{|c|c|c|c|}
\hline S. No. & OPINION & No. & PERCENT (\%) \\
\hline 1 & Strongly agree & 09 & 18 \\
\hline 2 & Agree & 25 & 50 \\
\hline 3 & Disagree & 09 & 18 \\
\hline 4 & Strongly disagree & 07 & 14 \\
\hline Total & \multicolumn{2}{|c|}{$\chi^{2}=28.08, \mathrm{df}=3, \chi 2(.05)=7.81$} \\
\hline
\end{tabular}

On asking to the officials of BHEL that PMS create a participative environment then only $18 \%$ were strongly agree and as a group of $50 \%$ were agree and said that it creates participative environment in our organization and $18 \%$ respondents were disagree and only 14 $\%$ were strongly disagree about it. The chi square value clearly indicates that the opinion of respondents was significantly different.

\section{1. 10. Employees are satisfied with the existing Performance Management System?}

\begin{tabular}{|c|c|c|c|}
\hline S. No. & OPINION & No. & PERCENT (\%) \\
\hline 1 & Strongly agree & 11 & 22 \\
\hline 2 & Agree & 21 & 42 \\
\hline 3 & Disagree & 14 & 28 \\
\hline 4 & Strongly disagree & 04 & 08 \\
\hline Total & \multicolumn{2}{|c|}{$\chi^{2}=11.92, \mathrm{df}=3, \chi 2(.05)=7.81$} \\
\hline
\end{tabular}

When it is asked to the officials that Employees are satisfied with the existing Performance Management System, then $22 \%$ were strongly agree and $42 \%$ were agree and said that they are satisfied and $28 \%$ and $8 \%$ were disagree and strongly disagree respectively.

The chi square value completely shows that the opinion of respondents was significantly different when it comes to satisfaction with the existing PMS.

\section{2. Questionnaire for BHEL employees and staff members}

\section{2. 1. Since how many years have you been working with this organization?}

On asking to the respondents that since when you are working with this organization, $22.5 \%$ were below 5 years and $24.5 \%$ of them were in between $5-10$ years and $25.5 \%$ were in between 10-15 years and remaining $27.5 \%$ were above 15 years. Hence chi square value depicts that the service time of respondents was significantly identical. 


\begin{tabular}{|c|l|c|c|}
\hline S. No. & OPINION & No. & PERCENT (\%) \\
\hline 1 & $0-5$ Years & 45 & 22.5 \\
\hline 2 & $5-10$ Years & 49 & 24.5 \\
\hline 3 & $10-15$ Years & 51 & 25.5 \\
\hline 4 & More than 15 Years & 55 & 27.5 \\
\hline Total & \multicolumn{2}{|c|}{$\chi^{2}=1.04, \mathrm{df}=3, \chi^{2}(.05)=7.81$} \\
\hline
\end{tabular}

\section{2. 2. Goals set for Performance Evaluation are mutually decided goals?}

\begin{tabular}{|c|c|c|c|}
\hline S. No. & OPINION & No. & PERCENT (\%) \\
\hline 1 & Strongly agree & 36 & 18 \\
\hline 2 & Agree & 84 & 42 \\
\hline 3 & Disagree & 57 & 28.5 \\
\hline 4 & Strongly disagree & 23 & 11.5 \\
\hline Total & \multicolumn{2}{|c|}{200} & 100 \\
\hline
\end{tabular}

On asking to the respondents that Goals set for Performance Evaluation are mutually decided goals, only $18 \%$ and $42 \%$ of them were strongly agree and agree in that order and $28.5 \%$ were disagree and $11.5 \%$ were strongly disagree with the statement. Also chi square value depicts that the opinion of respondents was significantly different.

\section{2. 3. Employees feel free to express their disagreement regarding the appraisal} decisions?

\begin{tabular}{|c|c|c|c|}
\hline S. No. & OPINION & No. & PERCENT (\%) \\
\hline 1 & Strongly agree & 39 & 19.5 \\
\hline 2 & Agree & 71 & 35.5 \\
\hline 3 & Disagree & 75 & 37.5 \\
\hline 4 & Strongly disagree & 15 & 7.5 \\
\hline Total & \multicolumn{2}{|c|}{$\chi^{2=48.24, \mathrm{df}=3, \chi 2(.05)=7.81} 100$} \\
\hline
\end{tabular}


When it was asked to the employees that they you feel free to express their disagreement regarding the appraisal decisions, $19.5 \%$ were strongly agree and $35.5 \%$ were agree While as a group of $37.5 \%$ and $7.5 \%$ were disagree and strongly disagree respectively. The chi square value completely shows that the opinion of respondents was significantly different on this fact.

\section{2. 4. The process and criteria of PMS is always well communicated before the time of appraising the performance?}

\begin{tabular}{|c|c|c|c|}
\hline S. No. & OPINION & No. & PERCENT (\%) \\
\hline 1 & Strongly agree & 25 & 12.5 \\
\hline 2 & Agree & 56 & 28 \\
\hline 3 & Disagree & 69 & 34.5 \\
\hline 4 & Strongly disagree & 50 & 25 \\
\hline Total & \multicolumn{2}{|c|}{200} & 100 \\
\hline
\end{tabular}

When it was asked to the employees that criteria of PMS is always well communicated before appraisal, then only $12.5 \%$ were strongly agree and $28 \%$ were agree While the majority of $34.5 \%$ and $25 \%$ were disagree and strongly disagree respectively.

The chi square value completely shows that the opinion of respondents was significantly different on this fact.

\section{2. 5. Employees are satisfied with the weight edge given against each activity that you} are supposed to perform in the specified period by PMS?

\begin{tabular}{|c|c|c|c|}
\hline S. No. & OPINION & No. & PERCENT (\%) \\
\hline 1 & Strongly agree & 34 & 17 \\
\hline 2 & Agree & 82 & 41 \\
\hline 3 & Disagree & 51 & 25.5 \\
\hline 4 & Strongly disagree & 33 & 16.5 \\
\hline Total & \multicolumn{2}{|c|}{$\chi^{2}=31.4, \mathrm{df}=3, \chi 2(.05)=7.81$} \\
\hline
\end{tabular}

On asking to the employees that you are satisfied with the weight edge given against each activity, then only $17 \%$ of respondents were strongly agree and $41 \%$ were agree and majority of only $25.5 \%$ and $16.5 \%$ of respondents were disagree and strongly disagree about it respectively.

The chi square value radically shows that opinion of the respondents was significantly different when it comes to weight edge given against each activity. 


\section{2. 6. Connecting individual goals with the organizational goals, helps in attaining career growth?}

\begin{tabular}{|c|c|c|c|}
\hline S. No. & OPINION & No. & PERCENT (\%) \\
\hline 1 & Strongly agree & 55 & 27.5 \\
\hline 2 & Agree & 78 & 39 \\
\hline 3 & Disagree & 41 & 20.5 \\
\hline 4 & Strongly disagree & 26 & 13 \\
\hline Total & & 200 & 100 \\
\hline
\end{tabular}

When it is asked to the employees that Connecting individual goals with the organizational goals, helps in attaining career growth, then $27.5 \%$ were strongly agree and 39 $\%$ were agree with this statement and $20.5 \%$ and $13 \%$ respondents were disagree and strongly disagree simultaneously. Also the chi square value radically shows that the opinion of respondents was significantly different.

\section{2. 7. The performance management system satisfies only monetary needs not the social needs?}

\begin{tabular}{|c|c|c|c|}
\hline S.NO. & OPINION & NO. & $\begin{array}{c}\text { PERCENT } \\
(\%)\end{array}$ \\
\hline 1 & $\begin{array}{l}\text { Strongly } \\
\text { agree }\end{array}$ & 44 & 22 \\
\hline 2 & Agree & 71 & 35.5 \\
\hline 3 & Disagree & 69 & 34.5 \\
\hline 4 & $\begin{array}{l}\text { Strongly } \\
\text { disagree }\end{array}$ & 16 & 08 \\
\hline Total & & 200 & 100 \\
\hline
\end{tabular}

When it was asked to the employees that The PMS satisfies only monetary needs not the social needs, then $22 \%$ were strongly agree and majority of $35.5 \%$ were agree While only $34.5 \%$ and $8 \%$ were disagree and strongly disagree respectively. The chi square value completely shows that the opinion of respondents was significantly different on this fact.

\section{2. 8. PMS provides an exposure to unleash the one's capabilities in the functioning of different department within the organization?}

When it was asked to the employees that PMS provides an opportunity to unleash the one's capabilities in the functioning of different department then, mass of $19.5 \%$ and $44.5 \%$ were strongly agree and agree respectively and only $18.5 \%$ and $17.5 \%$ were disagree and strongly disagree respectively by this statement. The chi square value radically shows that the opinion of respondents was significantly different. 


\begin{tabular}{|c|c|c|c|}
\hline S. No. & OPINION & No. & PERCENT (\%) \\
\hline 1 & Strongly agree & 39 & 19.5 \\
\hline 2 & Agree & 89 & 44.5 \\
\hline 3 & Disagree & 37 & 18.5 \\
\hline 4 & Strongly disagree & 35 & 17.5 \\
\hline Total & & 200 & 100 \\
\hline
\end{tabular}

\section{2. 9. Your leadership and interpersonal skills are developed due to Performance} Management System?

\begin{tabular}{|c|c|c|c|}
\hline S. No. & OPINION & No. & PERCENT (\%) \\
\hline 1 & Strongly agree & 53 & 26.5 \\
\hline 2 & Agree & 87 & 43.5 \\
\hline 3 & Disagree & 31 & 15.5 \\
\hline 4 & Strongly disagree & 29 & 14.5 \\
\hline Total & & 200 & 100 \\
\hline
\end{tabular}

On asking to the respondents that PMS helps in developing leadership and interpersonal skills, then $26.5 \%$ and $43.5 \%$ of them were strongly agree and agree in that order and only $15.5 \%$ were disagree and $14.5 \%$ were strongly disagree with the statement. Also chi square value depicts that the opinion of respondents was significantly different.

\section{2. 10. The promotions are strictly based on Performance Management System?}

\begin{tabular}{|c|c|c|c|}
\hline S. No. & OPINION & No. & PERCENT (\%) \\
\hline 1 & Strongly agree & 42 & 21 \\
\hline 2 & Agree & 61 & 30.5 \\
\hline 3 & Disagree & 56 & 28 \\
\hline 4 & Strongly disagree & 41 & 20.5 \\
\hline Total & & 200 & 100 \\
\hline
\end{tabular}

$\chi^{2}=6.04, \mathrm{df}=3, \chi^{2}(.05)=7.81$ 
When it is asked to the respondents that promotions are strictly based on Performance Management System, then $21 \%$ were strongly agree and $30.5 \%$ were agree and $28 \%$ and 20.5 $\%$ respondents were disagree and strongly disagree simultaneously.

Also the chi square value radically shows that the opinion of respondents was significantly identical when talking promotions based on PMS.

\section{FINDINGS}

- Most of the employees of BHEL belongs to different age groups and are spending dissimilar service period with the organization.

- The management of BHEL, Bhopal has defined the performance management process and system within the organization. But some officials of BHEL were not sure about it.

- Performance Management System is a regular process in BHEL which is conducted by the human resources department after a regular or defined time span.

- Most of the officials were having a different view regarding the transparency in the process of PMS

- Performance management process of BHEL provides a chance to employees of advancement and recognition within the organization.

- Most of the officials were in the favor that they consider all the factors facilitating and hindering performance at the time of appraisal.

- Job Description is clearly defined to the employees, so that they can perform their job without any hurdle.

- Most of the officials were identical on the matter that Performance of employees improves due to current Performance Management System.

- Performance Management System helps employee to set their individual goals with the organizational goals and achieve meaningful outcomes.

- The PMS implemented in BHEL creates a participative environment. Hence most of the employees are satisfied with the existing Performance Management System.

- Most of the employees said that, goals set for Performance Evaluation are mutually decided goals.

- Employees of BHEL were unlike while asking about feeling of freeness to express their disagreement regarding the appraisal decisions.

- The process and criteria of PMS is always well communicated by the management before the time of performance appraisal.

- Employee attains career growth, due to connecting individual goals with the organizational goals.

- The PMS of BHEL is lagging behind in satisfying social needs rather than satisfying only monetary needs.

- PMS of BHEL provides an opportunity to unleash the one's capabilities in the functioning of different department within the organization.

- Some employees said that promotions are not strictly based on PMS, somewhere seniority is considered for it. 


\section{CONCLUSION}

The overall purpose of this study was to test the key variables that are having strong influence on Performance management system with special reference to BHEL, Bhopal. We are also going to figure out the PM process, awareness level and satisfaction level of employees and how the PM system affects the performance and career development of employees in BHEL, Bhopal (M.P.)

Majority of employees in BHEL, Bhopal are well aware about the Performance Management system of the company. The employees have a complete idea about the various aspects of Performance evaluation in the company except those elements which are kept confidential. Employees are of the opinion that their evaluation should be done by seniors as well as by self. Employees in the organization are not happy with the non-transparency of the Performance Appraisal System. Employees have a common thinking that the ratings given should be revealed to the respective employee.

Since Performance measures are now widely used within public sector organizations, but there is a lack of evidence regarding their usefulness. Hence it is still not clear to what extent performance measures help agencies to achieve the goals.

There is a strong need for a healthy performance management system to be introduced in the government covering all organizations and different levels of functionaries. The alignment between individual performance and organizational goal is also of utmost importance by introducing an appropriate set of performance indicators. Measuring performance is useful only when it translates into action. Performance management tools by themselves do not create sustained high performance. It is important to create an environment conducive for effective and efficient performance with a system of rewards and punishment, besides building capacity at all levels of government to get results.

\section{SUGGESTIONS}

- Changing culture requires leaders to understand the learning process dynamics and how the learning and unlearning of assumptions and beliefs can be manipulated to modify behavior. Hence cultural aspects could be one of the areas of training. An organization's leadership has the responsibility to develop a positive culture to facilitate the acceptance of performance appraisal among managers and their employees.

- Employees naturally like to know how they are performing relative to what is expected from them. Performance feedback helps employees to know how well they have performed in comparison with the performance standards. Having day-to-day employeemanager interaction, through which the appraiser is provided with constructive feedback.

- Effective performance management requires equal standards against which employees are assessed. In the absence of equal standards, employees are assessed with subjectivity, which may destroy the process of appraisal and leave it as a body without soul. Therefore, the problem of unequal standards can be minimized by ensuring that the appraisal criterion is job-oriented.

- One performance appraisal program should not be designed to serve a numerous of purposes because it may be unclear and difficult $\&$ results into failure. The solution is to separate assessment program should be designed for development of employees. 
- Performance management system should be job-related. Job description should be given to the employees. Bring them into the line of organization's goals with the job objectives so that every employee's work lead to the organizational goal.

- Communicate management's expectations to the employee so that a widespread understanding will exist between management and the employee regarding the job expectations. The nature of job and the standards, on which the work is evaluated, should be communicated properly.

- Regular formal meetings should be held and feedback on performance should be given regularly and it should be offered to the employees concerning his performance and its relationship to the expectations taken into view by management.

- Constructive feedback instead of destructive feedback should be given in the form of comments so that employee does not get discourage and also employees do not leave the organization.

- Since the goal of performance management system is to achieve the organizational goal. Hence there is immense need to coach the employee before and after evaluating their performance. Provide the resources required by them to get to the management's expectations.

- Create a culture that provides constructive, ongoing, developmental feedback to all employees and Provide multisource feedback to employees along with tools to help employees improve in areas identified via the feedback.

- Deliver training and development for new and experienced employees that enhances critical competencies and behaviors.

- Provide ongoing opportunities (such as online assessments, third-party assessors, and so on) that enable employees to assess and develop their skills for current and future assignments.

- Create career development systems that identify, prepare, and promote employees whose experience and skills match the demands of higher-level positions.

- Provide fair appraisals that let employees know where they stand and provide useful information that drives employee goal setting and development.

- Create appraisal processes that enable employees to (i) provide input about their performance (via self-evaluation or discussion with the supervisor), and (ii) challenge their appraisals (for example, via a panel review by uninvolved managers).

- Award monetary and non-monetary recognitions to those who are performing well consistently.

- Use SMART technique for PMS i.e. S- SPECIFIC - set clear concrete goal, MMEASURABLE- quantity, quality, cost and time, A- ACHIEVABLE- realistic should extend you, R- RESULT ORIENTED- Deliverable, accomplishments, T- TIME BOUND- deadliness dates.

- Design the system which is free from biasness and favoritism because it discourages the employee to perform better in a long run case.

- Promotions should be strictly based on performance management system rather than seniority.

- In order to run the PMS more efficiently and to increase the work efficiency of the employees, managers should be properly trained. Training sessions regarding PMS should be conducted.

- Organizational objectives can be achieved successfully when there is a link or alignment between organizational and unit objectives so to avoid the conflict between team and 
organization's objectives Top level management should set their objectives with the consensus and involvement of low level management and supervisory staff.

\section{References}

[1] About Bhel, Bhopal, Available from http://www.bhelbpl.co.in/bplweb_new/About.aspx

[2] Akinyele S. T., Educational Research 1(8) (2010) 293-303.

[3] Akua Asantewaa Aforo1, Kodjo Asafo-Adjei Antwi, Journal of Business Management and Economics 3(8) (2012) 301-306.

[4] Al Bento, Regina Bento, Journal of Information Technology Management XVII(2) (2006) 23-32.

[5] Arun Verma, Pawan S. Budhwar, Angelo DeNisi, Performance management system - A global perspective, Routledge 270 Madison Ave, New York, 2008, pp. 55-67.

[6] Dipak Kumar Bhattacharya, "Performance management system and strategies", Pearson education, 2011, pp. 13-17.

[7] George Ndemo Ochoti, Elijah Maronga, Stephen Muathe, Robert Nyamao Nyabwanga, Peter Kibet Ronoh, International Journal of Business and Social Science 3(20) (2012) $37-46$.

[8] Javed Iqbal, Samina Naz, Mahnaz Aslam, Saba Arshad, Interdisciplinary Journal of Contemporary Research in Business 4(3) (2012) 709-728.

[9] Jawaria Andleeb Qureshi, Asad Shahjehan, Zia-ur-Rehman, Bilal Afsar, African Journal of Business Management 4(9) (2010) 1856-1862.

[10] Kothari C. R., "Research methodology - methods and techniques", New Age International Publishers, 2004, pp. 233-238.

[11] Mohammad Tanvi Newaz, International Journal of Business and Management Tomorrow 2(3) (2012) 1-10.

[12] Leena Toppo, Twinkle Prusty, IOSR Journal of Business and Management 3(5) (2012) 01-06.

[13] R. K. Sahu, “Performance management system”, Excel publication, 2007, pp. 95-119.

[14] Sharmistha Bhattacharjee, Santoshi Sengupta, VSRD-IJBMR 1(8) (2011) 496-513.

[15] T. V. Rao, (2011) "Performance management and appraisal systemsage publication India pvt. Ltd.”, Pearson education, 2011, pp. 75-80. 